me of a cure which could be given without the patient's knowledge, and which would not necessitate institutional treatment?

\section{Colourless Iodine}

Colonel R. J. Blackham (London, E.C.4), in reply to Dr. J. Jackson (Journal, May 29, p. 1144), writes: The tinctura iodi decolorata of the B.P.C. is prepared by dissolving iodine in 90 per cent. alcohol and then adding a strong solution of ammonia. The mixture is kept in a warm place until it becomes colourless. The German method of making the preparation consists in dissolving ten parts of iodine and sodium thiosulphate in an equal quantity of water, and then fifteen parts of a 10 per cent. solution of ammonia is added. The mixture is well shaken, and seventy-five parts of 90 per cent. alcohol is added. The preparation is kept for three days in a cool place and then filtered. It is therefore clear that these compounds are not preparations of the halogen, but are ammoniacal alcoholic solutions containing ammonium iodide and ammonium iodate, and consequently possess very little therapeutic value. In order to avoid staining in the treatment of rheumatic and pulmonary affections oily preparations such as unguentum iodi intinctum (Martindale) or iodex should be used.

\section{Rheumatism and Tuberculosis in General Practice}

Dr. H. V. Mitchell (Bournemouth) writes: I have read with much interest Dr. Bunting's letter in the Journal of May 15 (p. 1056). Having used Warren Crowe's vaccines in the treatment of rheumatic infections for several years I should like to confirm what Dr. Bunting says as to their general usefulness and the satisfactory results obtained by means of the small doses. One thing that has interested me particularly has been that by far the greatest number of patients that were having or had had this treatment did not contract influenza during the recent epidemic, although many were exposed to the infection in their own homes. This point is one of interest when so much work is being done to find a successful vaccine for influenza, although it may only be a coincidence. Dr. Warren Crowe, to whom I wrote asking for his opinion, replied: "It is a very common finding that patients under vaccine treatment do not get either severe colds or influenza to anything like the normal extent. The probable answer is that many cases are complicated by streptococcal infection, and this is prevented by the vaccine." It would be interesting to hear if others who use the vaccine have noticed in their cases results similar to the above.

\section{Income Tax}

\section{Earned Income Relief-Secrecy of Returns}

"ADVICE" explains that he is a partner in a firm, and out of his share of the profits pays interest, some under deduction of tax $(£ 50)$ and some to a bank in full- $£ 60$. Why should this fact reduce the relief on his earned income? The inspector of taxes has given the firm's agents particulars of his allowances, in spite of the fact that he had asked for such matters to be referred to himself only.

** That portion of the earnings which is paid away in the form of interest is regarded for purposes of relief as the (unearned) income of the lender and not as part of the borrower's own income. So far as ordinary interest is concerned the point was raised in the case of Adams $v$. Musker, in which it was decided that Section 17 of the Income Tax Act, 1918, applies to earned income. That section provides that a claimant shall not be entitled to relief in respect of any income the tax on which he is entitled to charge against any other person or to deduct out of any payment which he is liable to make to any other person. While this provision does not directly cover bank interest, it is thought that the courts would probably apply it by analogy. Tax is paid at standard rate on $£ 90$, but as tax on $£ 50$ is recoverable by deduction from the lender it is only on $£ 40$ that tax can be repaid at the full rate. The difficulty with regard to the secrecy of the allowances arises from the fact that partnership profits are assessed on the firm and not on the individual partners, and consequently the formal notice of assessment must show the aggregate of the allowances claimed by all the partners. The reference of that notice to the accountants by the senior partner of the firm was doubtless necessary to enable the net duty to be correctly apportioned between the partners.
Removal Expenses

"W. R." removed voluntarily to new premises, but continued to use the old premises for professional purposes only until a surgery was built at the new address. The inspector of taxes has disallowed $£ 4$, the cost of removing surgery fittings, etc., and one-third of the Schedule A assessment on the old premises up to the date they were completely vacated.

${ }_{*}^{*}$ The disallowance of the cost of removal is justified by a legal decision (Kitton $v$. The Aberdeen Granite Company), but seems a little harsh, as presumably - wear and tear allowance is not claimed on the fittings. If it is so claimed the $f 4$ can be added to the capital value for future allowances. As regards the Schedule A assessment, we know of no justification for adding the one-third for any period after residential use of the premises had ceased, and we should have thought that would have been admitted immediately the facts were made clear to the inspector.

\section{LETTERS, NOTES, ETC.}

\section{Posture}

Dr. Josiah OldFietd writes from Kingston, Jamaica: The evil effects of spinal malformation need not nowadays be stressed. The progressive kyphosis-so commonly looked upon as a necessary senile stoop -is not only aesthetically repellent but is physiologically injurious. We are to-day talking a great deal about replacing the $\mathrm{C} 3$ by the $\mathrm{A} 1$ in our race, but while gymnastic exercises and physical drills are excellent there is at present no definite aim at securing a graceful and erect posture as a permanent human carriage up to extreme old age. Yet the Greeks attained it two thousand years ago, and to-day in Jamaica I find such training in graceful carriage and erectness of spinal position that it is a pleasure to look at children and adults, at old men and aged women striding along mile after mile with easy step and swinging limbs and head erect. In Greeks and Jamaicans the secret of this physiological balance is to be found in the amphora and the basket always carried on the head. If in every school the pupils had a daily half-hour's drill in walking freely and easily with a tumbler of water on the head, we should develop a permanent habit posture which would oust the present shambling gait and round-shouldered stoop.

\section{Short-wave Therapy}

Dr. H. J. TAYlor, of the St. John Clinic, writes: My attention has recently been drawn to a letter by Dr. P. P. Dalton (May 29, p. 1144) in reply to one which I sent to you. My letter was not intended to be a counterblast to any work which Dr. P. P. Dalton has done, but as a simple statement which should be of interest to all who have any concern in shortwave therapy. With regard to the new evidence which Dr. Dalton is supposed to have produced, Sir Leonard Hill and myself will have something to say later, but I would draw Dr. Dalton's attention to previous literature on the subject. D'Arsonval in 1891-6 made (with long-wave diathermy, be it noted) very similar claims to those put forward as new evidence by Dr. Dalton. J. Audial in 1932, and N. Delherm and $H$. Fischgold in 1934, made exactly similar claims as Dr. Dalton's (1937). I fail to see, therefore, that any new evidence has arisen.

\section{Corrigenda}

Our note on Dr. Donald Hunter's lectures on Occupational Diseases (June 5, p. 1161) said that these had appeared as clinical supplements to the Guy's Hospital Gazette. We should have printed London Hospital Gazette.

In Dr. Gardiner-Hill's paper published in last week's Journal there is an error in the eighth line of the second paragraph under the heading "Differential Growth" on page 1241. "Counts of fourteen to twelve cells are common" should read "Counts of fourteen to twenty cells are common."

In Dr. Ralph Worrall's letter on a new treatment for chronic leucorrhoea which appeared on April 10 at page 781 we gave his prescription incorrectly. The amount of nitrate of silver should have been 16 grains, not $1 / 16$. The prescription should read:

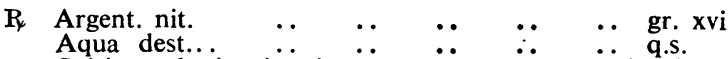

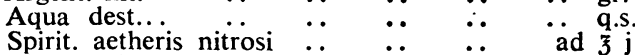

Fiat. applic.

Sig.: "Shake the bottle." 